NEWS

\title{
Temporary reprieve for stem cells
}

\section{Scientists face a rollercoaster ride as the $\mathrm{NIH}$ rushes to distribute funds.}

The National Institutes of Health is scrambling to get money out the door after the temporary reversal of a court injunction that abruptly shut down US government funding for human embryonic stem-cell research just 17 days earlier. Meanwhile, affected scientists are trying to keep up with the latest developments in an intensifying legal battle that will determine the future viability of their field.

The 9 September ruling by the Court of Appeals for the District of Columbia Circuit quashed a 23 August decision by federal district court Judge Royce Lamberth to shut down National Institutes of Health (NIH) funding for the research while he considers a lawsuit challenging that funding. In a statement issued after the ban was lifted, NIH director Francis Collins said, "We are pleased with the Court's interim ruling, which will allow this important, life-saving research to continue while we present further arguments to the Court in the

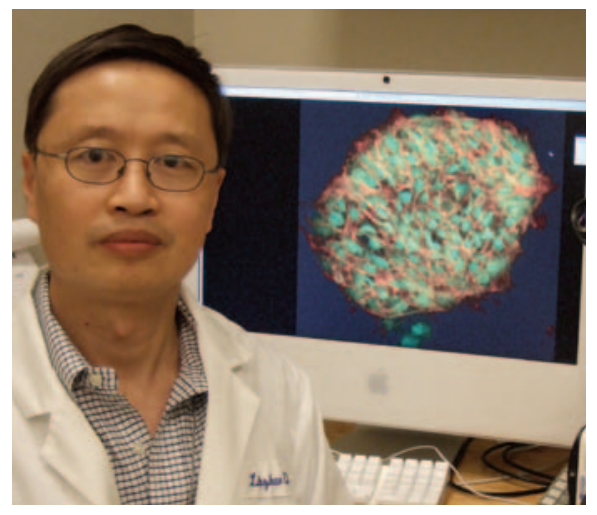

Stem-cell researcher Linzhao Cheng hopes to receive an overdue NIH grant this week.

weeks to come".

However, the reprieve could end as soon as 20 September - the deadline set by the appeals court for litigants to weigh in on whether government funding should be frozen until the case before Lamberth is decided on its merits. Meanwhile, the two plaintiffs in the case, James Sherley of the Boston Biomedical Research Institute in Watertown, Massachusetts, and Theresa Deisher of AVM Biotechnology in Seattle, Washington, last week filed for a summary judgment, asking Lamberth to provide a swift decision on their suit without a court hearing. Sherley and Deisher, who are supported by religious groups that oppose human embryonic stem-cell research, say that their own work, which involves adult stems cells, is being jeopardized by the NIH's funding policies.

Within hours of last week's ruling, senior NIH officials were advised to speed new grants out the door, fast-track the review of grant applications and fund 24 existing, multi-year grants that are still owed a total of US $\$ 54$ million in the government's 2010 fiscal year, which ends on 30 September. By late

\section{Looking for other funders}

Although the 23 August ban on federal funding for human embryonic stem-cell research applied only to the US National Institutes of Health $(\mathrm{NIH})$, other funding entities have not been isolated from the turmoil. Scientists whose NIH grants were frozen were left to consider what other the funding landscape reveals what a challenge it would be to fill the gap if the ban became permanent. Foundations provide just $10 \%$ of the funding for work on human embryonic stem cells, estimates Douglas Melton, co-director of the Harvard Stem Cell Institute in Cambridge, Massachusetts, which is largely supported by private donors. "If doing stemcell science is like having a full meal, philanthropy [as a means of supporting such work] is like having appetizers," says Melton. Private money and philanthropy are nowhere near sufficient to replace NIH funds, he says.

Still, some private funders are resources, public or private, might be available to them, but a review of mobilizing to help researchers to bridge the gap. The New York Stem Cell Foundation, a non-profit lab funded by private philanthropic grants, as well as some state money, plans to raise $\$ 5$ million in the next two months to expand its facilities so that it can provide lab space, cell storage and other services to researchers who may have to interrupt their work.

"A lot of our work is collaborative," says Susan Solomon, the foundation's chief executive. She adds that the foundation is best able to support cutting-edge work with modest funding, leading the way for others to scale-up new avenues of research. But with an operating budget of only "We're not the NIH," she says.

Currently, few state governments have committed significant budget dollars to funding stem-cell research. The California Institute for Regenerative Medicine has the largest state-grant-giving programme (see 'No substitute'), having awarded about $\$ 327$ million $\$ 6.5$ million, it can do only so much. in research funding to human embryonic stem-cell researchers there since 2006. Other states, such as Massachusetts and Wisconsin, have provided funding for institutions and infrastructure to do stem-cell work.

Corporate funding is also unlikely to fill the gaps. Although biotech Geron, of Menlo Park, California, has funded collaborations with about 15 US labs since it turned to stem-cell research in the mid-nineties and, in 2008, London-based pharmaceutical giant GlaxoSmithKline signed a \$25-million collaboration with the Harvard Stem Cell Institute, few such deals have been sealed. And, says Stephen Brozak, president of WBB Securities, a life-science brokerage and analysis firm in San Diego, California, they are likely to become scarcer as the current uncertainty scares off investors.

Brozak thinks that uncertainly will hamper all stem-cell startups, whether they work with embryonic stem cells or the adult variety, which critics of embryonic stem-cell work often advocate as a palatable alternative. Few on Wall Street know enough to differentiate between the two, he says.

"I would say you could pretty much describe the 2010s as the lost decade for stem-cell research," says Brozak.

Alla Katsnelson

\section{NO SUBSTITUTE}

Estimated federal and state contributions to stem-cell research in 2009, including human embryonic stem (hES)-cell work

Total stem-cell funding hES-cell funding

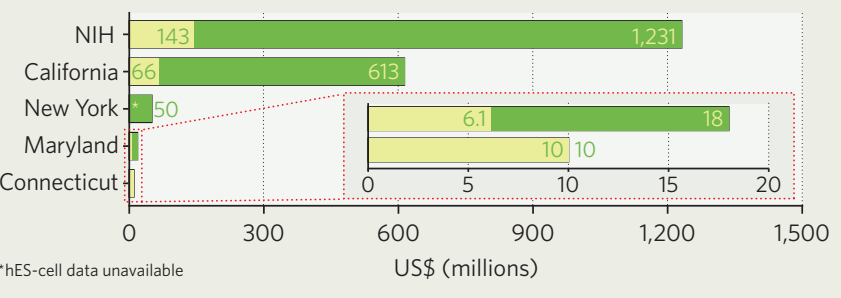


afternoon last Thursday, top NIH administrators had announced to staff, by e-mail, that the scientists the agency supports, on and off its campus in Bethesda, Maryland, could resume their experiments immediately, and that funding and peer review would begin apace.

"I am delighted to see that the NIH took swift action," says Linzhao Cheng, a stem-cell researcher at the Institute for Cell Engineering at Johns Hopkins University in Baltimore, Maryland. Cheng had suspended all hiring, purchases and planning for a large NIH grant that had scored very highly in peer review. $\mathrm{He}$ had originally expected to receive funding on 1 September. Still, he says, even if he receives payment this week, "we just cannot do science like this, turning the switch on and off".

Peer review is also suffering, Cheng says. Two weeks ago, he was instructed by the NIH to ignore any grants for projects using human embryonic stem cells as he prepares to participate in a study section next month. He hadn't heard of any change to those instructions by the end of last week. By now it will be difficult, he says, to give human embryonic stem-cell proposals the careful reading they deserve in advance of the meeting on 12-13 October.

Cheng also draws on Maryland state funds for his work, but that is not an option for many other researchers (see "Looking for other funders"). Meri Firpo, an assistant professor at the University of Minnesota Stem Cell Institute in Minneapolis, says that until the future of federal funding becomes more certain, she will plan for a long-term shutdown. She is currently rewriting an NIH grant, due for submission in October, to exclude human embryonic stem cells. And she is restructuring the projects of students who receive federal support to exclude the controversial human cells. "We are going forward with the same question mark as before," Firpo says.

The uncertainty extends to stem-cell researchers based on the NIH campus. Although several are hurrying to expand valued cell lines while they can, some are switching to work with induced pluripotent stem cells, which are not derived from embryos. "No one is willing to take any risks at this point and start any big experiments," says one on-campus researcher, "because it's possible that in two weeks all experiments with these cells will really be shut down for a long time."

As the legal battle continues, proponents are pressing for Congress to pass a bill that would explicitly make it legal for the NIH to fund human embryonic stem-cell research. While rejecting a request to stay his ruling, Lamberth wrote, "Congress remains perfectly free to amend or revise the statute."

Meredith Wadman

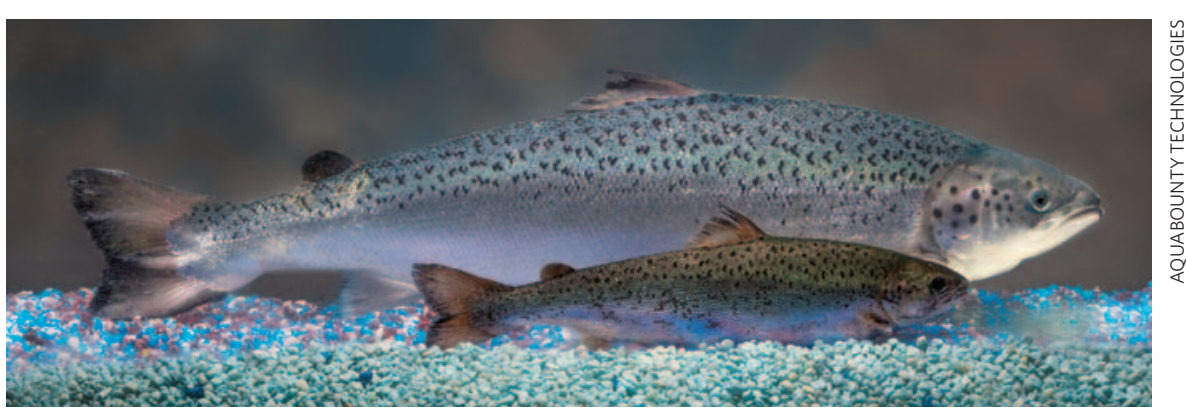

Transgenic fish go large

A genetically modified animal is on the brink of making an appearance on US dinner tables for the first time. The Food and Drug Administration (FDA) is expected to approve a genetically modified (GM) Atlantic salmon that grows twice as fast as wild Atlantics, reaching market weight in a year and a half instead of three. Approval could come as soon as next week.

The fish contains a single copy of a DNA sequence that includes code for a Chinook salmon growth hormone and regulatory sequences derived from Chinook salmon and the eel-like ocean pout. Whereas Atlantic salmon normally stop growing in the winter, the GM fish produces growth hormones throughout the year. Developer AquaBounty Technologies, based in Waltham, Massachusetts, has spent more than a decade shepherding the fish towards approval in a new regulatory landscape. In 2009, the FDA decided to classify GM traits in animals as veterinary drugs. Some have criticized this decision, as it allows companies to shield some details of their product from public view as proprietary information (see Nature doi:10.1038/ news.2008.1120; 2010).

To appease critics, the FDA has posted all the information behind its decision on the salmon online, and has opened much of the deliberations of an advisory body - the Veterinary Medicine Advisory Committee (VMAC) - to the public. Next week the VMAC will hold public sessions to hear about the science, safety, environmental impact and possible labelling of the fish. The FDA's Center for Veterinary Medicine, which will decide on approval after hearing from the VMAC, has already released a favourable report.

Some environmental groups are concerned that the fish might escape from their pens and mate with wild Atlantic salmon. "There is always going to be a possibility of escape," says Peter Bridson, aquaculture research manager at the Monterey Bay Aquarium in California. "We would oppose the approval of the current application."

AquaBounty's chief executive Ronald Stotish says those concerns are misplaced. More than $99 \%$ of his salmon are triploid, which renders them sterile, and the fish are farmed inland, in large tanks fitted with filters and baffles to imprison eggs, smolt and fish. "The possibility of an escape or an event with any possibility to interact with the wild population is

According to Mark Abrahams, a biologist at Memorial University in St John's, Newfoundland, Canada, the transgenic fish's ramped-up metabolism is maladapted to life in the wild. "They are willing to incur huge risks to gain access to food," he says, allowing predators to pick off the fish easily.

The next GM animal on dinner plates may be the Enviropig, developed at the University of Guelph, Ontario, Canada, and submitted to the FDA for approval. The pig can better absorb phosphorus from its food, reducing the phosphorus content of its manure. High-phosphorus manure can induce algal blooms in waterways.

There are no requests for authorization of transgenic food animals pending in the European Union, and the European Food Safety Authority, based in Parma, Italy, is just beginning to draft regulatory guidelines. For now, AquaBounty plans to market its salmon only in the United States. "Other countries are interested but they are all looking to the United States for the regulatory imprimatur," says Stotish. Emma Marris 